\title{
1-2-20＼cjkstart层板断裂におけるMRIの有用性と限界
}

\author{
長崎大学整形外科: \\ ○朝長 匡（ともながただし）、伊藤信之、衛藤正雄 \\ 井上博文、 M. E. ラッビ
}

【目的】腱板断裂の診断におけるMRIの有用性と問題点を検討した。【対象および方法】 手術、関節鏡を行い腱板の状態を確認し、かつ術前にMRI検査を行っていた80例 (80肩) を対象とした。男性74例、女性6例で手術時年齢は30～80歳（平均54.7歳）であった。 MRI装置はGE社製Signa 1.5T超伝導型で、肩関節用表面コイルを用い、 4 5 mmスライ スで撮像した。T1強調横断像と斜位冠状断像挹よびT2 強調斜位冠状断像と斜位矢状断 像より診断した。手術記録より腱板断裂の大きさ、完全か不全かをを調査しMRI診断と 比較した。【結果】術前MRI検查の診断は完全断裂が57例、不全断裂が19例、インピン ジメント症候群が4例であった。術中診断では完全断裂63例、不全断裂11例、断裂なし6 例であった。完全断裂の正診率は $90.0 \%$ で、不全断裂の正診率は $87.5 \%$ であった。断裂 の大きさにおいて MRI像と手術所見に強い相関関係を認めた。

\section{1-2-21 腱板断裂患者の肩甲上腕リズムの分析}

\author{
長崎大学整形外科 \\ ○白石公太郎（しらいしこうたろう） \\ 伊藤信之、衛籐正雄、朝長 匡、井上博文、進藤裕幸
}

【目的】肩腱板断裂例では肩甲上腕リズムに乱れを認める。今回、我々は本症例の手術前 後の上肢挙上時の肩甲骨の動きを分析したので報告する。

【対象および方法】腱板断裂例に対し、McLaughlin法による腱板再建術を行った患者9例 を対象とした。年齢は 45〜78歳であった。広視野のX線透視装置を用いて scapular plane での挙上運動をデジタルビデオで撮影した。この画像上で有甲骨の 3 点をプロットし、そ の座標からコンピュータで肩甲骨の 3 次元的な動きを計算した。術直前と術後 4 力月〜2年 10カ月の動きを分析し比較検討した。

【結果】術後、可動域の改善に伴い上方回旋角は改善した。また、術前肩甲骨は最大挙上 時に前方へ傾斜していたが、術後後方への傾斜が増加し、健常者のリズムに近似してい た。 


\title{
1-2-22 肩峰の形態と画像所見の対比
}

\author{
長崎大学整形外科 \\ ○松林昌平（まつばやししょうへい）、伊藤信之 \\ 衛藤正雄、朝長 匡、井上博文、進藤裕幸
}

【目的と方法】1986年、Biglianiらは死体の検索により肩峰の形態を 3 種類（Type 1:flat type. Type 2:curved type. Type 3:hooked type）に分類し、腱板完全断裂例は Type 3 に多 いことを報告した。以後、本疾患とX線像やMRI像で得られた屃峰との関係が報告さ れてきた。我々は肩峰外側部の標本のX線像、薄切切片像、MRI像、一部は単純X線 像（Scapular Y view）で得られた形態が一致するか否かを調べた。

【対象および結果】対象は 45例（42〜 83歳）で、腱板断裂例に Type 3 が多いという事は なかった。切除した標本と MRI像の形態は 70\%で一致した。Scapular Y viewとの形態 の一致率は低かった。

\section{1-2-23 腱板断裂の肩峰下面の変化}

\author{
長崎大学整形外科 \\ ○山崎浩二郎（やまさきこうじろう）、伊藤信之、衛藤正雄 \\ 朝長 匡、井上博文、進藤裕幸
}

【目的】腱板断裂例に対し我々は肩峰外側端の切除を行ってきた。部分切除した肩峰 下面の病理所見より変性状態を調べ、impingementの原因を推察するとともに変性に 関与した因子を明らかにしてきた。今回は症例を増やしたので報告する。

【対象および方法】対象は45例（42８３歳）である。切除した肩峰を外側端に平 行に肩鎖関節の方へ薄切標本を作成しH.E. 染色を行った。この標本により肩峰下面の 変化が見られる範囲と変性の程度を調べた。

【結果】変性の範囲と程度は加令と共に増加していき、若年者例では高齢者例に比し 変性の範囲は狭かった。また外傷との相関はみられなかった。この結果より肩板断裂 の原因が退行性変性であることと考えた。 


\section{1-2-24 いわゆるLoose shoulderを伴った}

\section{右肩関節随意性後方脱臼の一治験例}

南川整形外科病院

○黒木理秀（くろきょしひで）、高岸直人

南川博道、蒲地龍太郎、石河利之

【目的】今回我々は比較的希な随意性後方脱臼を経験し術後3年の経過追跡を行い得た ので報告する。【症例】13歳、男性。【主訴】亜脱臼感、鈍痛、腕立て伏せ不能。【現 病歴】小学生の頃よりの症状が増強し、当院紹介受診。来院時左右ともにloose shoulder を認め、voluntaryに後方へ肩を脱臼させる事が出来た。脱臼時広背筋のtensionが増大し、 動作筋電図検査では随意脱臼時に広背筋の活動電位が著明に上昇していた。術後3年の 現在患者では随意性の脱臼を行えなくなっておりまた鈍痛、倦点感と言った主訴も改 善している。【考察】後方脱臼の手術法では関節包の縫縮のみでは不完全であるとの 報告が多い。本症例ではScott法に準じ、臼蓋中枢側の骨切りと後下方よりの骨移植、 及び主作働筋である広背筋切離術を併用することでより確実な手術効果が得られたも のと思われる。

\section{1-2-25 肩腱板広範囲断裂の治療経験}

\section{公立玉名中央病院整形外科}

○阿部靖之（あべやすゆき）、中野哲雄、

越智龍弥、清水泰宏、藤原一徳

肩腱板広範囲断裂に対する手術療法の成績を検討した。症例は6例で、手術時年齢は58 才 72才平均 63.2 才、男性 5 例、女性 1 例。受傷機転は転倒 3 例、労災 2 例、不明 1 例。 受傷から手術までの期間は 23 日〜 1.5 年平均 4.3 力月。手術後経過観察期間は $3 \sim 7$ 力、 平均5.0力月。全例手術前にMRIを撮像。MRIにて棘上筋腱の完全断裂は1例を除いて確 認できた。1例は関節造影にて完全断裂と診断。術前の日整会肩関節疾患治療判定基準

（JOAスコア）は37点〜 73点、平均56.2点で、特に疼痛 $10 / 30$ 、肩屈曲 $7.5 / 15$ と低か つた。断裂部のサイズは平均 $53 \times 50 \mathrm{~cm}$ 。大腿筋膜を使用したパッチ法とDebeyre法を併 用し腱板再建。術後は肩関節外転装具で外転 100 度程度で固定。他動挙上運動は術後 1 週で開始、術後約6週で装具除去し自動挙上訓練を開始。最終観察時のJOAスコアは77 〜 100点、平均 89.2 点と全例改善した。 